\title{
Pengembangan UKM Turubuk Pangsit Makanan Khas Kabupaten Karawang
}

\author{
Rahman Tanjung ${ }^{1}$, Hendar $^{2}$, Juhadi $^{3}$, Opan Arifudin ${ }^{4}$ \\ 1,2Program Studi Pendidikan Guru Madrasah Ibtidaiyah, STIT Rakeyan Santang \\ Karawang, Indonesia \\ ${ }^{3}$ Program Studi Perbankan Syariah, STEI Al-Amar Subang, Indonesia \\ ${ }^{4}$ Program Studi Ekonomi Syariah, STEI Al-Amar Subang, Indonesia
}

\begin{abstract}
ABSTRAK
Turubuk pangsit merupakan makanan khas Kabupaten Karawang yang terbuat dari tanaman turubuk yang merupakan tanaman sejenis palawija namun pohonnya seperti pohon tebu. Turubuk pangsit merupakan makanan yang dihasilkan dari UKM Turubuk pangsit Desa Cintalaksana kecamatan Tegalwaru Kabupaten Karawang. Masalah UKM Turubuk pangsit Desa Cintalaksana kecamatan Tegalwaru Kabupaten Karawang yakni sumber modal, tenaga kerja, bahan baku dan pemasaran. Metode penyelesaian masalah yang digunakan berdasar pada pendekatan manajemen dalam meningkatkan hasil produksi dan hasil penjualan dengan 4 (empat) tahapan pelaksanaan program yaitu persiapan, pelaksanaan, evaluasi dan pelaporan. Hasil program pendampingan UKM turubuk pangsit makanan khas Kabupaten Karawang di Desa Cintalaksana kecamatan Tegalwaru Kabupaten Karawang Jawa Barat, menunjukkan adanya perubahan yang dialami oleh mitra program selama dan setelah pelaksanaan program dilakukan dapat dilihat dari 3 indikator perubahan yang dapat disimpulkan berdasar pada data-data yang diperoleh dalam setiap monitoring dan evaluasi program terhadap mitra. Indikator ini terdiri dari pengelolaan, produktifitas dan Hasil Penjualan.
\end{abstract}

Kata Kunci: Produksi, Pemasaran, Inovasi

\section{PENDAHULUAN}

Kabupaten Karawang saat ini tidak hanya terkenal sebagai kota industri, tetapi juga merupakan wilayah yang subur karena juga termasuk wilayah lumbung padi nasional. Namun hasil alam saat ini bukan hanya padi, tetapi masih banyak hasil alam yang dihasilkan oleh Kabupaten Karawang. Salah satu hasil alam Kabupaten Karawang yakni turubuk, tanaman turubuk ini merupakan tanaman endemik Jawa Barat yang ada di Kabupaten Karawang. Turubuk merupakan tanaman sejenis palawija namun pohonnya seperti pohon tebu, dengan nama latin saccharum edule hassk. Turubuk ini merupakan tanaman yang unik dan sangat khas tumbuh di wilayah Loji kecamatan Tegalwaru. Manfaat yang dihasilkan dari tanaman turubuk ini sangat banyak, sehingga bisa diolah menjadi berbagai jenis masakan dari dibakar, dikukus, dipeses, disayur, dan bisa dimasak sesuai dengan selera.

Hal ini merupakan potensi yang besar dari tanaman turubuk, sehingga olahan dari tanaman turubus ini menjadi oleh-oleh khas Kabupaten Karawang. Banyak usaha kecil menengah (UKM) di wilayah Loji kecamatan Tegalwaru mengolah turubuk pangsit. Sehingga turubuk pangsit menjadi makanan khas Kabupaten Karawang yang sangat digemari. Namun yang menjadi masalah dari UKM turubuk pangsit ini adalah pemasaran, hal ini diketahui turubuk pangsit cukup sulit masuk pada pasar besar seperti supermarket. Oleh karena itu, sebuah UKM harus mampu mengikuti perkembangan zaman dalam rangka terus bertahan dan berkembang. Menurut (Arifudin, 2020) bahwa perkembangan dalam dunia usaha di Indonesia saat ini yang semakin cepat dan pesat berakibat juga pada perubahan budaya. Sehingga UKM turubuk pangsit sebagai sebuah organisasi dituntut untuk mempunyai budaya yang membedakan dengan organisasi lain yang sejenis.

Dengan kondisi yang terjadi, pemerintah pada tahun 2009 mencanangkan tahun industri kreatif yang diyakini merupakan industri penggerak sektor rill ditengah ancaman melambatnya perekonomian akibat krisis global. Melalui Inpres No. 6 tahun 2009 mengenai 
pengembangan industri kreatif kepada 28 instansi pemerintah pusat dan daerah untuk mendukung kebijakan pengembangan industri kreatif tahun 2009-2015 yakni pengembangan kegiatan ekonomi berdasarkan pada kreatifitas, keterampilan, bakat individu yang bernilai ekonomi dan berpengaruh pada kesejahteraan masyarakat Indonesia. Peningkatan kesejahteraan hanya mungkin bila tanah dan modal mampu meningkatkan produksi lebih cepat dibanding angkatan tenaga kerja.

Usaha Kecil dan Menengah (UKM) di Indonesia memiliki peran yang sangat penting terutama dalam hal penciptaan kesempatan kerja. Hal ini didasarkan pada kenyataan bahwa jumlah angkatan kerja di Indonesia sangat melimpah mengikuti jumlah penduduk yang besar sehingga usaha besar tidak sanggup menyerap semua pencari kerja dan ketidaksanggupan usaha besar dalam menciptakan kesempatan kerja yang besar disebabkan karena memang pada umumnya kelompok usaha tersebut relatif padat modal, sedangkan UKM relatif padat karya. Sehingga tujuan pengabdian masyarakat terkait pengembangan UKM turubuk pangsit makanan khas Kabupaten Karawang di Desa Cintalaksana kecamatan Tegalwaru sangat vital bagi upaya memberikan kemajuan pada UKM turubuk pangsit yang dikelola di Desa Cintalaksana kecamatan Tegalwaru Kabupaten Karawang. Turubuk pangsit adalah satu camilan yang bercita rasa gurih dan juga sangat renyah dengan berbahan dasar turubuk, siap disajikan dengan lauk-pauk lain sebagai teman makan yang nikmat dan lezat.

UKM merupakan Industri kecil di pedesaan dikenal sebagai tambahan sumber pendapatan keluarga dan juga sebagai penunjang kegiatan perekonomian masyarakat Desa. Ditengah-tengah Kabupaten Karawang menjadi Wilayah Industri, sehingga berdatangan para pendatang yang menambah persaingan mencari kerja. UKM turubuk pangsit ini menjadi alternatif ditengah-tengah persaingan mencari kerja. Diharapkan lahirnya Industri pedesaan mempunyai arti penting dalam usaha mengurangi tingkat kemiskinan di pedesaan atau dengan kata lain orang yang bekerja atau karyawan diharapkan dapat meningkatkan kesejahteraannya. Menurut (Arifudin, 2019) bahwa karyawan adalah setiap orang yang bekerja dengan menjual tenaganya (Fisik dan Pikiran) kepada suatu perusahan dan memperoleh balas jasa sesuai dengan peraturan dan perjanjian. Sehingga dengan UKM Turubuk pangsit meningkat maka karyawan akan mengalami peningkatan kesejahteraan juga.

Dalam rangka meningkatkan kesejahteraan masyarakat pedesaan tercermin pada sasaran pembangunan ekonomi skala besar kini telah menjadi perioritas pengembangan kedepan. Hal ini sesuai dengan intruksi presiden No. 6 Tahun 2009 tentang dukungan pengembangan ekonomi kreatif. Dukungan ini diharapkan untuk mengembangkan ekonomi yang ada dipedesaan sehingga dapat berpengaruh secara nyata bagi perekonomian ekonomi. Turubuk pangsit ini merupakan inovasi hasil pangan Kabupaten Karawang, yang mana tanaman turubuk memiliki manfaat menyembuhkan berbagai penyakit seperti kolestrol tinggi, meningkatkan system imun tubuh, penambah energi, mencegah oesteoporosis, meringankan gelaja depresi, menyembuhkan batuk kering, mencegah stroke dan lainnya.

UKM karena dikelola secara padat karya memiliki masalah-masalah yang sangat mendasar seperti sumber modal, tenaga kerja, bahan baku dan pemasaran. Modal sebagai dana yang digunakan untuk menjalankan kegiatan produksi sangatlah penting dalam strategi untuk mengembangkan sebuah usaha. Kekuatan yang dimiliki usaha dapat berasal dari modal yang dimiliki. Marketing atau pemasaran merupakan kegiatan penting dari perusahaan yang menghasilkan produk untuk dijual, dengan tujuan memperoleh keuntungan. Dengan keuntungan tersebut diharapkan perusahaan bersangkutan bukan saja dapat mempertahankan kelanjutan usahanya, tetapi juga dapat dikembangkan lebih besar. 


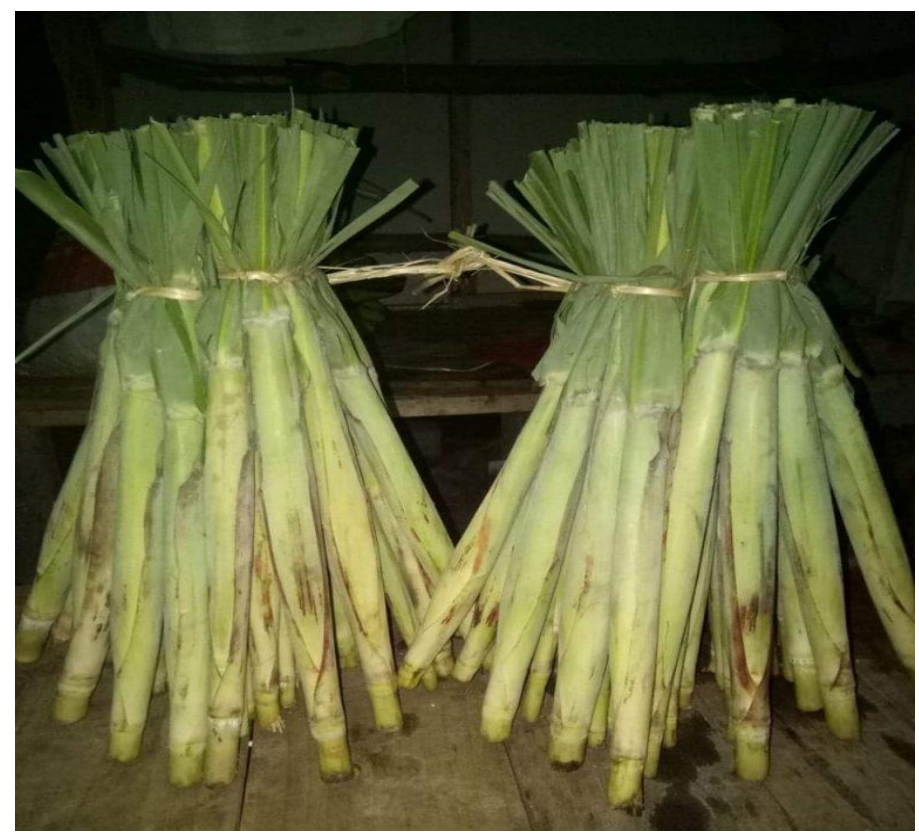

Gambar 1.Turubuk

Sebuah UKM dalam rangka meningkatkan hasil penjualan, harus menggunakan metode pemasaran yang sesuai dengan kemampuan UKM tersebut. Menurut Kotler dalam (Arifudin \& Tanjung, 2020) bahwa inti dari pemasaran adalah mengidentifikasi dan memenuhi kebutuhan manusia dan sosial. Sehingga lebih lanjut bahwa pemasaran adalah suatu fungsi organisasi dan serangkaian proses untuk menciptakan, mengkomunikasikan, dan memberikan nilai kepada pelanggan dan untuk mengelola hubungan pelanggan dengan cara yang mengguntungkan organisasi dan pemangku kepentingannya. Pendapat lain menurut (Tambajong, 2013) bahwa pemasaran adalah suatu sistem dari kegiatan bisnis yang dirancang untuk merencanakan, menentukan harga, mempromosikan dan mendistribusikan produk yang dapat memuaskan keinginan dalam mencapai tujuan perusahaan.

Dalam upaya memperluas pemasaran ini, dibutuhkan inovasi dalam produksi. Menurut Shepherd dalam (Damayanti, 2020) bahwa inovasi tidak hanya terbatas pada benda atau barang hasil produksi, tetapi juga mencakup sikap hidup, perilaku, atau gerakangerakan menuju proses perubahan di dalam segala bentuk tata kehidupan masyarakat. Inovasi ini akan berdampak pada kemajuan UKM Turubuk pangsit. Menurut pendapat (Sari, 2015) bahwa inovasi selalu menjadi kunci keberhasilan dan kesuksesan suatu usaha. Sehingga dalam rangka meningkatkan produksi dan hasil penjualan dibutuhkan inovasi yang dilakukan UMKM.

Pemasaran yang baik perlu didukung oleh produksi yang baik pula, khususnya dalam mutu produk. Produksi menurut Miller dan Mainers dalam (Tanjung, 2020) sebagai penggunaan atau pemanfaatan sumber daya yang mengubah suatu komoditi menjadi komoditi lainnya yang sama sekali berbeda, baik dalam pengertian apa, dan dimana atau kapan komoditi-komoditi tersebut dialokasikan, maupun dalam pengertian apa yang dikerjakan oleh konsumen terhadap komoditi itu. sedangkan mutu produk menurut (Fasa, 2020) dapat didefinisikan sebagai keunggulan dalam suatu produk bila dibandingkan dengan produk pesaing dilihat dari sudut pandang pelanggan.

Berdasarkan hal ini bahwa pengabdian kepada masyarakat terkait UKM turubuk pangsit makanan khas Kabupaten Karawang di Desa Cintalaksana kecamatan Tegalwaru dilakukan dengan pendampingan pada mitra dalam proses pemasaran turubuk pangsit, inovasi turubuk pangsit dan peningkatan hasil produksi turubuk pangsit. Hal ini yang 
dilakukan oleh pengabdi dalam mendampingi mitra UKM turubuk pangsit makanan khas Kabupaten Karawang di Desa Cintalaksana kecamatan Tegalwaru.

\section{Manfaat Pengabdian Pada Masyarakat}

Dari kegiatan pengabdian pada masyarakat ini diharapkan masyarakat khususnya yang terlibat dalam UKM turubuk pangsit memperoleh kesejahteraan dengan mengoptimalkan pengelolaan produksi dengan pendekatan manajemen, konsep pemasaran dan inovasi produk terkait hasil penjualan UKM turubuk pangsit makanan khas Kabupaten Karawang di Desa Cintalaksana kecamatan Tegalwaru. Selain itu kegiatan pengabdian pada masyarakat ini diharapkan dapat melestarikan makanan tradisional Kabupaten Karawang secara umum khas Jawa Barat, ditengah bermunculannya makanan-makanan dari luar negeri.

\section{Solusi Dan Target Luaran}

Kegiatan pengabdian pada masyarakat berupa pengembangan UKM turubuk pangsit makanan khas Kabupaten Karawang di Desa Cintalaksana kecamatan Tegalwaru terkait meningkatkan hasil produksi dan hasil penjualan, sebagai upaya membantu kesejahteraan masyarakat Desa Cintalaksana kecamatan Tegalwaru Kabupaten Karawang. Oleh karena itu target dan sasaran pendampingan ini terhadap mitra UKM dan masyarakat yang bergerak dalam UKM Turubuk pangsit ini. Dengan adanya Pendampingan UKM dalam meningkatkan hasil produksi dan hasil penjualan turubuk pangsit makanan khas Kabupaten Karawang, dapat memberikan kemanfaatan dan solusi yakni sebagai berikut :

1. Membantu memperluas pemasaran turubuk pangsit.

2. Memperbaiki kemasan produk turubuk pangsit dengan membuat kemasan didesain sesuai dengan standar yang telah di tetapkan Dinas Kesehatan dan agar lebih menarik.

3. Menerapkan manajemen pada proses produksi UKM turubuk pangsit.

Target luaran Pendampingan pengembangan UKM turubuk pangsit makanan khas Kabupaten Karawang di Desa Cintalaksana kecamatan Tegalwaru adalah sebagai berikut :

1. Menumbuhkan inovasi dalam menjalankan usaha.

2. Meningkatkan etos kerja dengan pendekatan manajemen agar hasil produksi meningkat.

3. Meningkatkan pengetahuan mengenai pemasaran konvensional maupun online agar hasil penjualan meningkat.

4. Meningkatkan pendapatan UMKM turubuk pangsit.

\section{METODE PELAKSANAAN}

Metode dalam pelaksanaan program pengabdian masyarakat interdisipliner yang dilakukan oleh Dosen pada 2 (dua) perguruan tinggi dilingkungan kementerian agama yakni STIT Rakeyan Santang Karawang dan STEI Al-Amar Subang. Dalam mendampingi UKM turubuk pangsit makanan khas Kabupaten Karawang di Desa Cintalaksana kecamatan Tegalwaru Kabupaten Karawang Jawa Barat dilakukan dengan beberapa tahapan pelaksanaan program, yaitu tahapan awal, tahapan pelaksanaan, tahapan monitoring dan evaluasi, dan tahapan pelaporan.

Tahapan awal diantaranya adalah Dosen dengan menyiapkan data-data yang dibutuhkan terkait UKM turubuk pangsit makanan khas Kabupaten Karawang terkait metode yang tepat digunakan dengan melihat kultur di Desa yang bersangkutan sebagai pertimbangan, menyiapkan program-program pengabdian masyarakat untuk di sosialisasikan kepada UKM turubuk pangsit makanan khas Kabupaten Karawang, dan 
menyiapkan peralatan, sarana-prasarana pendukung untuk pelaksanaan program dan formula strategi pelaksanaan program secara tahap demi tahap berdasarkan prioritas program pendampingan UKM turubuk pangsit makanan khas Kabupaten Karawang.

Tahapan pelaksanaan diantaranya adalah mengemukakan strategi proses pelaksanaan program pendampingan UKM turubuk pangsit untuk menerapkan pola manajemen terhadap mitra sehingga diharapkan memberikan dampak terhadap mitra sasaran program sesuai dengan tujuan pengabdian masyarakat pendampingan UKM turubuk pangsit, komunikasi sinergi dengan mitra, koordinasi terkait progress dari pengabdian masyarakat pendampingan UKM turubuk pangsit ini baik berupa data kuantitatif yang diukur selama pelaksanaan program, dan data kuantitatif ini merupakan referensi yang terus dipantau oleh pengabdi yang dihasilkan pada mitra sasaran sebagai data hasil kegiatan, baik data secara kuantitatif (misalnya jumlah produksi, jumlah omzet, jumlah kader masyarakat, luasan lahan, jumlah tanaman dll) maupun data kualitatif (misalnya kualitas produk, jenis produk, diversifikasi produk, perubahan perilaku masyarakat, keberadaan manajemen usaha/manajemen sosial dan sebagainya).

Tahapan monitoring dan evaluasi diantaranya adalah proses monitoring dan evaluasi terhadap pelaksanaan program dilakukan setiap minggu dalam 3 (tiga) bulan masa pengabdian masyarakat pendampingan, dan metode evaluasinya yang digunakan menggunakan metode deskriptif yaitu penelitian lapangan (Field Research) dengan penyelidikan mendalam yang dilakukan dengan suatu prosedur penelitian lapangan. Penelitian ini juga menggunakan data deskriptif kualitatif, yaitu penelitian yang ditujukan untuk mendiskripsikan atau menggambarkan fenomena-fenomena yang ada, baik fenomena yang bersifat alamiah ataupun rekayasa manusia.

Tahapan pelaporan diantaranya adalah pada tahapan ini, dilaporkan semua proses rangkaian kegiatan pengabdian dan output dari kegiatan ini. Pada tahap pelaporan ini, pengabdian kepada masyarakat terkait UKM turubuk pangsit makanan khas Kabupaten Karawang di Desa Cintalaksana kecamatan Tegalwaru dengan data-data yang di dapat pada mitra dalam proses pemasaran turubuk pangsit, inovasi turubuk pangsit dan peningkatan hasil produksi turubuk pangsit.

\section{HASIL DAN PEMBAHASAN}

Berdasarkan hasil dari pengabdian masyarakat interdisipliner yang dilakukan oleh Dosen pada 2 (dua) perguruan tinggi dilingkungan kementerian agama yakni STIT Rakeyan Santang Karawang dan STEI Al-Amar Subang dengan program pendampingan UKM turubuk pangsit makanan khas Kabupaten Karawang di Desa Cintalaksana kecamatan Tegalwaru Kabupaten Karawang Jawa Barat dapat dijelaskan hasil dan luaran program serta dampaknya terhadap perubahan mitra selama proses pendampingan mengalami peningkatan secara signifikan baik dari hasil produksi maupun penjualan dari produksi.

Hal ini dapat dilihat dari berbagai tahapan pengabdian masyarakat yang dilakukan yakni sebagai berikut :

\section{Tahapan Awal}

Pada tahap ini dilaksanakan observasi ke lokasi mitra dan wawancara dengan pemilik usaha UKM Turubuk Pangsit. Dari hasil observasi dan wawancara dengan mitra ditemukan permasalahan yang dialami oleh mitra sebagai berikut:

1. Usaha mitra terhambat dengan masalah pemasaran

2. Mitra mengalami kendala dalam peningkatan produksi turubuk pangsit

3. Mitra tidak memiliki kemasan yang memadai untuk dijual lebih luas. 
Permasalahan-permasalahan di atas perlu diatasi agar usaha mitra dapat lebih berkembang lagi. Berdasarkan permasalahan yang ditemui di atas maka solusi yang ditawarkan pengabdian kepada masyarakat pada UKM turubuk pangsit makanan khas Kabupaten Karawang di Desa Cintalaksana kecamatan Tegalwaru Kabupaten Karawang Jawa Barat sebagai mitra dalam kegiatan pengabdian ini terbagi pada aspek produksi dan pemasaran produk, yaitu :

1. Aspek Produksi

Solusi dari aspek produksi yang ditawarkan oleh dosen pendamping dalam pengabdian ini adalah sebagai berikut :

1) Membantu perluasan pemasaran produk turubuk pangsit

2) Memperbaiki kemasan produk turubuk pangsit dengan membuat kemasan didesain sesuai dengan standar yang telah di tetapkan Dinas Kesehatan dan agar lebih menarik.

3) Menerapkan manajemen pada proses produksi UKM turubuk pangsit.

2. Aspek Pemasaran

UKM turubuk pangsit berkualitas yang telah dihasilkan dapat memperluas tempat pemasaran dengan pemanfaatan sosial media dan platform online dalam pemasaran produk. Solusi dari permasalahan pemasaran yang ditawarkan dalam Program Kemitraan Masyarakat ini adalah memperluas pemasaran ke pasar modern dan pemasaran secara online.

\section{Tahapan Pelaksanaan}

Dalam produksi mitra mengalami masalah karena proses produksi dilakukan tanpa pendekatan manajemen. Hal ini terlihat dari jam kerja yang tidak jelas, perencanaan produksi yang belum ada dan capaian produksi yang tidak jelas setiap waktunya. Hal ini terjadi karena semua pekerjanya juga merupak ibu rumah tangga yang mengurus keluarganya. Tim pengabdi mendampingi mitra dalam mengelola UKM turubuk pangsit dengan pendekatan manajemen dan memperluas pemasaran menggunakan platform online serta ke toko-toko yang lebih besar.

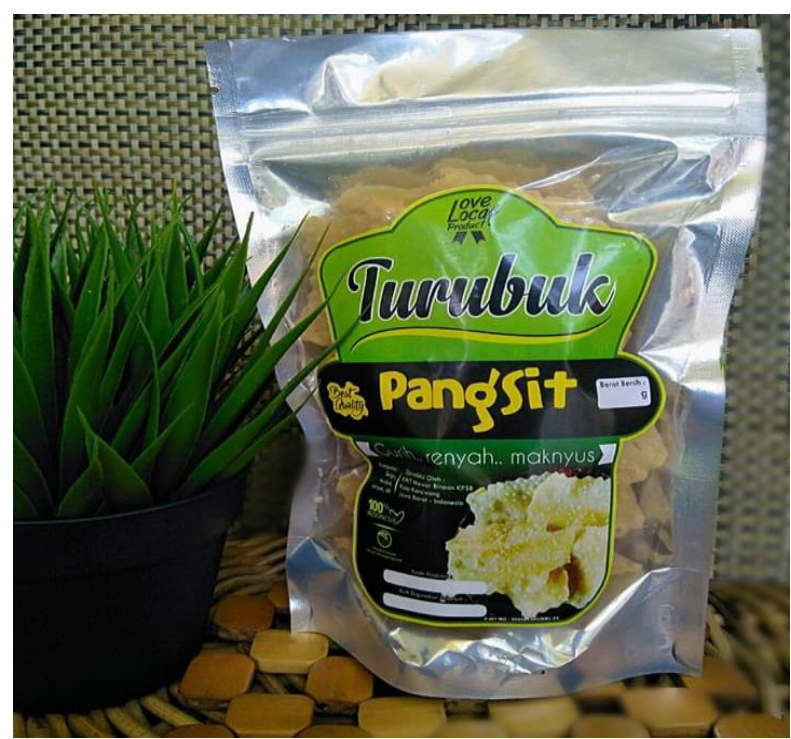

Gambar2. Kemasan Baru Turubuk Pangsit

Dampak dari program pengabdian masyarakat Dosen STIT Rakeyan Santang Karawang dan STEI Al-Amar Subang dengan program pendampingan UKM turubuk 
pangsit makanan khas Kabupaten Karawang di Desa Cintalaksana kecamatan Tegalwaru Kabupaten Karawang Jawa Barat terhadap mitra sangat besar terkait peningkatan hasil produksi maupun penjualan dari produksi berdasar data setiap bulan dengan rentang waktu pendampingan selama 3 (tiga) bulan dari bulan agustus, september dan oktober tahun 2019. Perlu diketahui bahwa dalam penyelenggaraan produksi ini hanya melibatkan 5 (lima) orang pekerja pada UKM turubuk pangsit makanan khas Kabupaten Karawang di Desa Cintalaksana kecamatan Tegalwaru Kabupaten Karawang Jawa Barat. Program yang dilakukan adalah pendekatan manajemen terkait jam kerja yang dibuat secara terstruktur dengan waktu 8 jam. Hal ini merupakan perubahan dari jam kerja yang tidak tentu dalam penyelenggaraan produksi UKM tersebut.

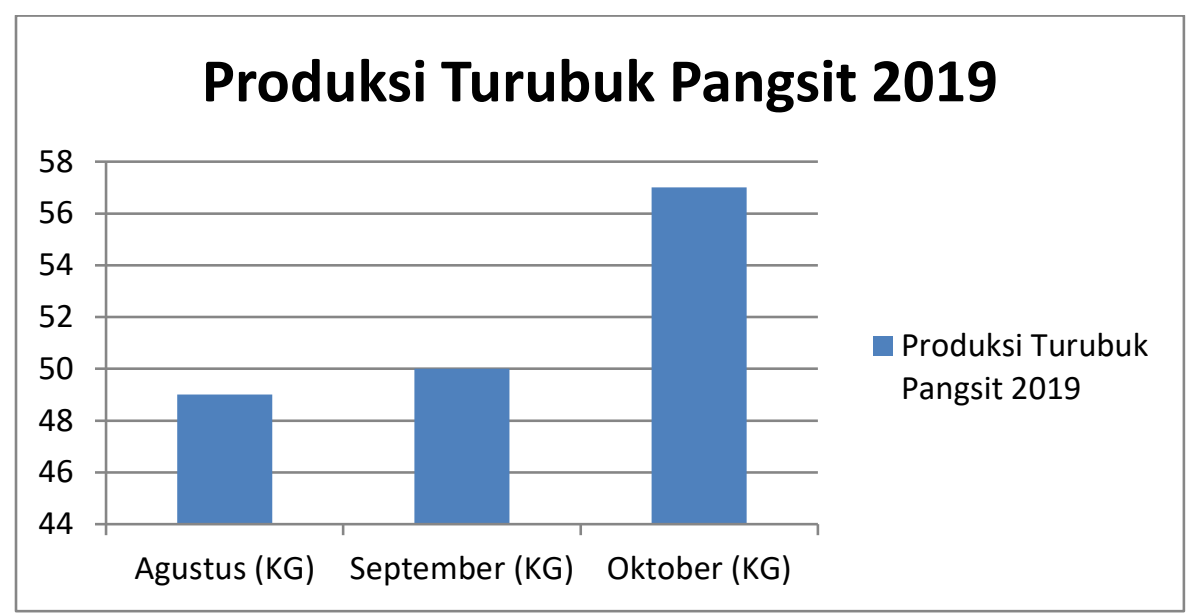

Diagram 1. Peningkatan Jumlah produksi Turubuk Pangsit 2019

Program pendampingan UKM turubuk pangsit makanan khas Kabupaten Karawang di Desa Cintalaksana kecamatan Tegalwaru Kabupaten Karawang Jawa Barat adalah meningkatkan jumlah produksi dan hasil penjualan. Hal ini sesuai dengan design awal program pendampingan terhadap mitra, berdasarkan data-data yang diperoleh tahun 2018 pada 3 (tiga) bulan yakni agustus, september dan oktober sebelum pendampingan pada dilakukan adalah sebagai berikut :

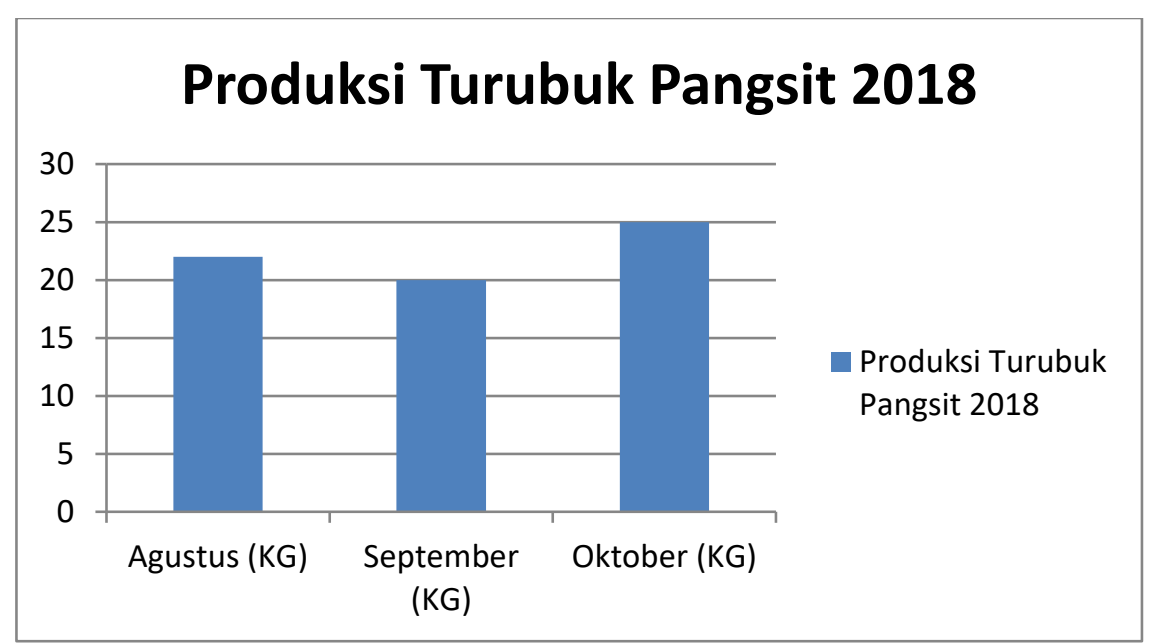

Diagram 2. Data Produksi Sebelum Pendampingan 2018

Dengan pendekatan manajemen yang dilakukan oleh Dosen STIT Rakeyan Santang Karawang dan STEI Al-Amar Subang pada pendampingan UKM turubuk pangsit makanan 
khas Kabupaten Karawang di Desa Cintalaksana kecamatan Tegalwaru Kabupaten Karawang Jawa Barat, ini sangat efektif terhadap pencapaian tujuan program pendampingan dalam meningkatkan hasil produksi dan penjualan turubuk pangsit. Metode pemanfaatan manajemen memiliki peran vital dalam pencapaian tujuan program pendampingan terhadap mitra, UKM tersebut pada awalnya dikelola secara sederhana tanpa pola.

Adapun terkait penjualan turubuk pangsit yang biasanya hanya berdasarkan pesanan masyarakat yang membutuhkan. Pendekatan marketing dilakukan oleh Dosen STIT Rakeyan Santang Karawang dan STEI Al-Amar Subang dengan memanfaatkan sosial media dan jasa antar, sehingga pemesanan tidak hanya dilakukan secara konvensional saja. Berdasarkan data yang diperoleh pada rentang waktu pendampingan selama 3 (tiga) bulan dari bulan agustus, september dan oktober tahun 2019 mengalami peningkatan yang signifikan.

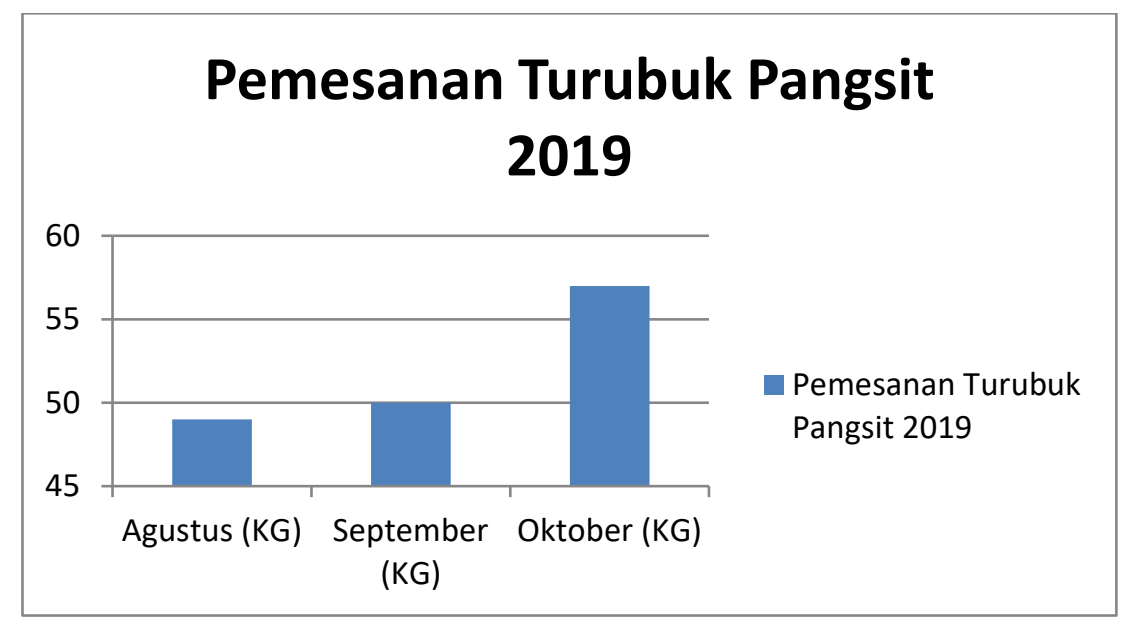

Diagram 3. Data Pesanan Setelah Pendampingan 2019

\section{Tahapan Monitoring dan Evaluasi}

Dalam melaksanakan program pendampingan UKM turubuk pangsit makanan khas Kabupaten Karawang di Desa Cintalaksana kecamatan Tegalwaru Kabupaten Karawang Jawa Barat, ada berbagai kendala yang dihadapi oleh Dosen STIT Rakeyan Santang Karawang dan STEI Al-Amar Subang dalam memberikan pendampingan mitra. Kendala dilapangan adalah merubah kultur pengelolaan UKM, karena pada awalnya UKM dikelola tanpa adanya pendekatan manajemen dengan menggunakan pola sederhana tanpa ada aturan waktu maupun target produksi. Kendala ini sangat berpengaruh terhadap ketercapain program sehingga pada bulan ke-1 pendampingan dalam meningkatkan hasil produksi dan penjualan tidak cukup signifikan dengan data hasil sebelum program pendampingan. Solusi yang diambil oleh Dosen STIT Rakeyan Santang Karawang dan STEI Al-Amar Subang dalam merubah kultur adalah dengan orientasi hasil sehingga para pekerja dan pemilik UKM mendapat stimulus dalam mengimplementasikan pendekatan manajemen pada UKM turubuk pangsit makanan khas Kabupaten Karawang di Desa Cintalaksana kecamatan Tegalwaru Kabupaten Karawang Jawa Barat.

Dalam penyelenggaraan program pendampingan UMKM turubuk pangsit makanan khas Kabupaten Karawang di Desa Cintalaksana kecamatan Tegalwaru Kabupaten Karawang Jawa Barat penggunaan metode pendampingan, monitoring dan evaluasi pelaksanaan program untuk mencapai tujuan program sangat efektif. Hal ini sebagai dampak dari proses komunikasi sangat baik antara pendamping dan mitra. Mitra sangat terbantu akan 
kehadiran pendampingan baik pada tataran teoritis maupun praktis. Hal ini pun mendapat dukungan dari pemerintah setempat terkait salah satu program Desa yakni satu Desa satu produk.

Penyelenggaraan program pendampingan UKM turubuk pangsit makanan khas Kabupaten Karawang di Desa Cintalaksana kecamatan Tegalwaru Kabupaten Karawang Jawa Barat, terkait perubahan yang dialami oleh mitra program selama dan setelah pelaksanaan program dilakukan dapat dilihat dari 3 indikator perubahan yang dapat disimpulkan berdasar pada data-data yang diperoleh dalam setiap monitoring dan evaluasi program terhadap mitra. Indikator ini terdiri dari pengelolaan, produktifitas dan Hasil Penjualan.

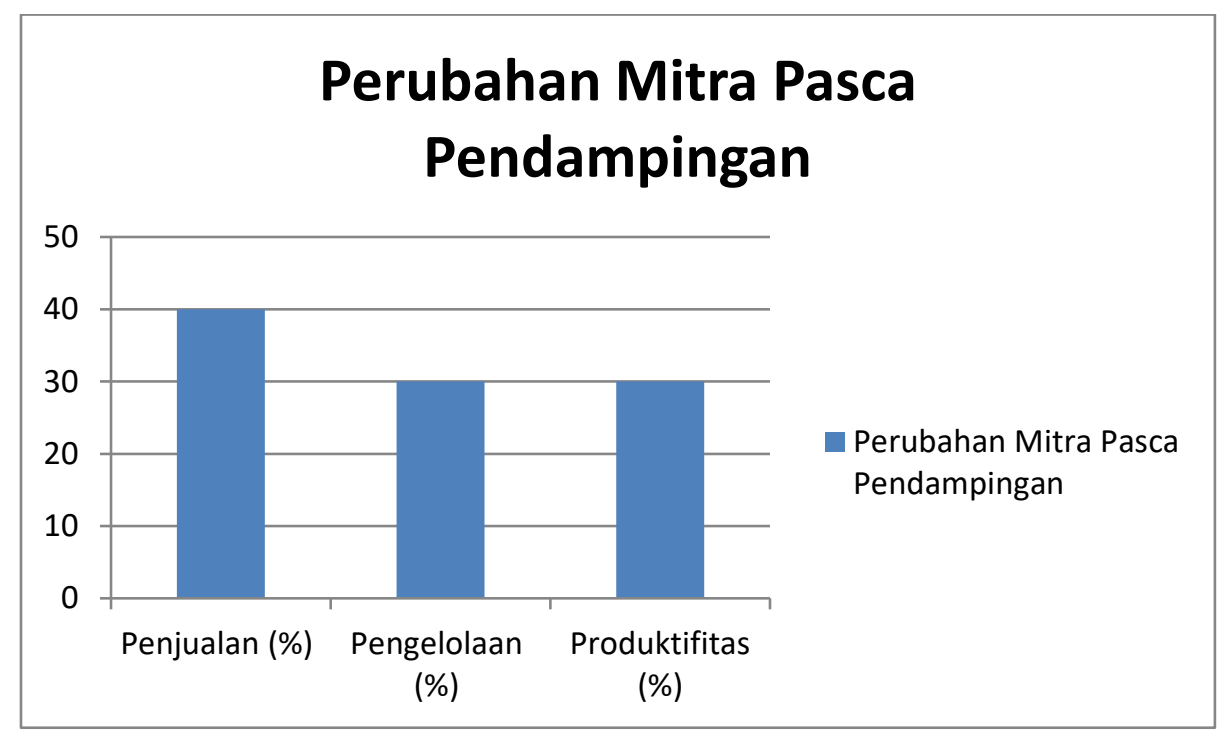

Diagram 1.6. Data evaluasi perubahan mitra 2019

Data-data empiris yang di dapat selama proses pendampingan UKM turubuk pangsit makanan khas Kabupaten Karawang di Desa Cintalaksana kecamatan Tegalwaru Kabupaten Karawang Jawa Barat sejalan dengan teori Jhon Stuart Mill dalam (Bernadetha, 2020) yang mengemukakan bahwa pembangunan ekonomi sebagai fungsi dari tanah, tenaga kerja, dan modal. Sementara tanah dan tenaga kerja adalah dua faktor produksi yang asli, dan modal adalah persediaan yang dikumpulkan dari produk-produk tenaga kerja sebelumnya. Peningkatan kesejahteraan hanya mungkin bila tanah dan modal mampu meningkatkan produksi lebih cepat dibanding angkatan tenaga kerja. Tujuan pendampingan UKM turubuk pangsit makanan khas Kabupaten Karawang di Desa Cintalaksana kecamatan Tegalwaru Kabupaten Karawang Jawa Barat adalah pada peningkatan hasil produksi agar meningkatkan kesejahteraan masyarakat Desa pada UKM Turubuk pangsit hanya dapat dicapai apabila produksi dapat ditingkatkan.

\section{KESIMPULAN DAN SARAN}

\section{Kesimpulan}

Berdasar pada kesimpulan dari program pengabdian masyarakat Dosen STIT Rakeyan Santang Karawang dan STEI Al-Amar Subang dengan program pendampingan UKM turubuk pangsit makanan khas Kabupaten Karawang di Desa Cintalaksana kecamatan Tegalwaru Kabupaten Karawang Jawa Barat terhadap mitra dalam meningkatkan jumlah produksi dan hasil penjualan, hal ini sesuai dengan design awal program pendampingan 
terhadap mitra berdasarkan data-data yang ada diperoleh 3 (tiga) bulan sebelum pendampingan. Program pendampingan UKM turubuk pangsit makanan khas Kabupaten Karawang di Desa Cintalaksana kecamatan Tegalwaru Kabupaten Karawang Jawa Barat, terkait perubahan yang dialami oleh mitra program selama dan setelah pelaksanaan program dilakukan dapat dilihat dari 3 indikator perubahan yang dapat disimpulkan berdasar pada data-data yang diperoleh dalam setiap monitoring dan evaluasi program terhadap mitra. Indikator ini terdiri dari pengelolaan, produktifitas dan Hasil Penjualan.

\section{Saran}

Adapun saran yang bisa diberikan atas pelaksanaan Program pengabdian kepada masyarakat Dosen STIT Rakeyan Santang Karawang dan STEI Al-Amar Subang dengan program pendampingan UKM turubuk pangsit makanan khas Kabupaten Karawang di Desa Cintalaksana kecamatan Tegalwaru Kabupaten Karawang Jawa Barat, adalah sebagai berikut :

1. Untuk terus konsisten dalam menjalankan UKM Turubuk pangsit dibutuhkan pendekatan manajemen yg konsekuen sehingga perbaikan bukan saat pendampingan saja tetapi juga menjadi budaya baru UKM.

2. Dibutuhkan semangat terus belajar guna terus berinovasi dalam pengembanag usaha ke depan agar bisa bersaing dengan usaha yang lain.

3. Adanya kesamaan tujuan antara pemilik dan karyawan agar UKM Turubuk pangsit makanan khas Kabupaten Karawang ini bisa mensejahteraan kehidupan semuanya.

\section{DAFTAR PUSTAKA}

Arifudin, O. (2020). Analisis Budaya Organisasi Dan Komitmen Organisasi Karyawan Bank Swasta Nasional Di Kota Bandung. Jurnal Ilmiah MEA (Manajemen, Ekonomi, Dan Akuntansi), 4(2), 73-87.

Arifudin, O. (2019). Pengaruh Kompensasi Terhadap Kinerja Karyawan Di PT. GLOBAL (PT.GM). Jurnal Ilmiah MEA (Manajemen, Ekonomi, \& Akuntansi), 3(2), 184-190.

Arifudin \& Tanjung. (2020). Manajemen Pemasaran Pendidikan. Bandung: Widina Bhakti Persada.

Bernadetha. (2020). Manajemen Humas Pada Lembaga Pendidikan. Bandung: Widina Bhakti Persada.

Damayanti, F. (2020). Prilaku konsumen dan perkembangannya di era digital. Bandung: Widina Bhakti Persada.

Fasa, I. (2020). Eksistensi Bisnis Islami Di Era Revolusi Industri 4.0. Bandung: Widina Bhakti Persada.

Sari, S. W. (2015). Pendampingan Pengembangan Geblek Pedas Pada Wirausaha Pembuatan Geblek Di Dusun Dusun Balong V, Desa Banjarsari, Kecamatan Samigaluh, Kulon Progo, Yogyakarta. Jurnal Inovasi Dan Kewirausahaan, 4(3), 206210.

Tambajong, G. (2013). Bauran Pemasaran Pengaruhnya Terhadap Penjualan Sepeda Motor Yamaha Di Pt. Sarana Niaga Megah Kerta Manado. Jurnal EMBA, 1(1), 1291-1301.

Tanjung, R. (2020). Kepemimpinan \& Prilaku Organisasi Konsep Dan Perkembangan. Bandung: Widina Bhakti Persada. 